\title{
Effects of Auditory Translation Priming under Divided Attention in Unbalanced Persian-English Bilinguals
}

\author{
Saeedeh Shafiee Nahrkhalaji ${ }^{1}$, Ahmad Reza Lotfi ${ }^{1} \&$ Mansour Koosha ${ }^{1}$ \\ ${ }^{1}$ Faculty of Foreign Languages, Isfahan (Khorasgan) Branch, Islamic Azad University, Isfahan, Iran \\ Correspondence: Saeedeh Shafiee Nahrkhalaji, Faculty of Foreign Languages, Isfahan (Khorasgan) Branch, \\ Islamic Azad University, University Blvd, Arqavanieh, Jey Street, Isfahan, Iran. E-mail: \\ shafieesaeedeh@yahoo.com
}

Received: July 14, 2014 Accepted: September 16, 2014 Online Published: October 30, 2014

doi:10.5539/ass.v10n21p109 URL: http://dx.doi.org/10.5539/ass.v10n21p109

\begin{abstract}
In bilingual studies, repetition priming across languages or translation priming can be used to examine the mental representations of bilingual lexicon and language in memory. Motivated to demonstrate the effects of dividing attention during implicit retrieval of $\mathrm{L}_{2}$ spoken words, we investigated the nature of the processes involved in translation priming. In so doing, we used behavioral measures (i.e. reaction time and accuracy) to study 60 Persian-English unbalanced proficient bilinguals performing translation priming in two language directions under two attention conditions. The present study compared a divided attention (DA) condition, in which participants carried out the priming task in auditory modality while simultaneously performing a secondary task in visual modality, and a full attention (FA) condition, in which participants performed only the priming task. We also examined secondary tasks costs produced by memory tests. Despite significant priming effects and symmetrical pattern of translation priming in the FA condition, translation priming effects in $\mathrm{L}_{2}$-to- $\mathrm{L}_{1}$ direction were absent in the DA condition. The secondary task was disrupted by memory test in this direction as well. The paper ends with discussion on the role of attention in $\mathrm{L}_{2}$ spoken word processing and language direction in translation priming in light of models of bilingual memory.
\end{abstract}

Keywords: divided attention, language direction, implicit retrieval, translation priming, unbalanced bilingual

\section{Introduction}

In psycholinguistic research into bilingualism, repetition priming across languages or translation priming have been used to examine the mental representations of bilingual lexicon. Translation priming is an experimental procedure where a target (e.g. sky) is preceded by its translation in another language (e.g. âsemân in Persian) resulting in facilitated processing. The occurrence of such facilitation indicates that the two words in a translation pair share the same underlying representation, thus suggesting language integration. The absence of a translation priming effect, on the other hand, indicates that a word and its translation access to different representations.

Cross-language influences appear to exist in both directions. However, regarding the language direction effects, translation priming studies have revealed contradictory findings. The dominant influence of a bilingual's first language on $\mathrm{L}_{2}$ processing has been acknowledged in a number of studies (e.g. Duyck, 2005; Marian \& Spivey, 2003; Schoonbaert, Hartsuiker \& Pickering, 2007). Some studies (e.g. De Groot, Dannenburg, \& Van Hell, 1994; La Heij, Hooglander, Kerling, \& Van der Velden, 1996) suggested that language direction has no significant effect on translation and some others (e.g. De Groot \& Poot, 1997; Midgley, Holcomb, \& Grainger, 2009) obtained facilitatory effect of translation priming direction is $\mathrm{L}_{1}-\mathrm{L}_{2}$.

According to the Revised Hierarchical Model (RHM - Kroll \& Stewart, 1994), second language learners acquire $\mathrm{L}_{2}$ words through $\mathrm{L}_{2}-$ to- $\mathrm{L}_{1}$ translation pairs in initial stages of learning leading to stronger $\mathrm{L}_{2}$ to $\mathrm{L}_{1}$ connections. However, Geyer, Holcomb, Midgley, Grainger (2010) described that the RHM-style models are compatible for early $\mathrm{L}_{2}$ acquisition. According to these researchers, as proficiency in bilinguals increases, direct links between the $\mathrm{L}_{2}$ word forms and their conceptual representations gradually are established through developing a pathway attached to $\mathrm{L}_{1}$ lexicon. Therefore, early bilinguals will rely on $\mathrm{L}_{1}$ word form for processing $\mathrm{L}_{2}$ more often, whereas proficient bilinguals will benefit considerably from $\mathrm{L}_{2}$ word forms and concept mediation representations resulting in similar facilitative translation priming effects in both directions. In fact, 
asymmetrical pattern of translation priming effects ate attenuated at very high levels of $\mathrm{L}_{2}$ competence and representation of translation pairs in bilingual memory seems to vary across different proficiency level. The developmental version of the Bilingual Interactive-Activation model (BIA-d - Grainger, Midgley, \& Holcomb, 2010) accounts for proficient bilingualism. According to Grainger et al. (2010), direct links between $\mathrm{L}_{2}$ word forms and conceptual representations dominate throughout the process of semantic access with gradual domination of excitatory connections established between lexical representations in the early stages of $\mathrm{L}_{2}$ vocabulary acquisition.

With participants who had to read mixed lists of $\mathrm{L}_{1}$ and $\mathrm{L}_{2}$ words silently for meaning, Alvarez, Holcomb \& Graingern (2003) put the RHM to the test using ERP recordings. The researchers have reported significant translation priming effects emerged when primes were in $\mathrm{L}_{2}$ and targets in $\mathrm{L}_{1}$ as compared to $\mathrm{L}_{1}-$ to- $_{2}$ translation condition. The results provided support for the RHM suggesting that translation priming from $\mathrm{L}_{2}$ to $\mathrm{L}_{1}$ would be created by activation of the $\mathrm{L}_{1}$ target word's lexical representation by the $\mathrm{L}_{2}$ prime word. Geyer et al. (2010) still attributed this result to low proficiency level of participants in their second language. With highly proficient bilinguals participating in a mixed-language lexical decision task, they revealed further evidence for crucial role of $\mathrm{L}_{2}$ proficiency level in symmetrical pattern of translation priming effects. Accounting for the RHM and the BIA-d models, Geyer et al. (2010) argued that the connection between $\mathrm{L}_{2}$ word forms and their $\mathrm{L}_{1}$ equivalents would increase in strength and any automatic translation of the $\mathrm{L}_{2}$ word into its $\mathrm{L}_{1}$ equivalent would decrease as $\mathrm{L}_{2}$ proficiency increases. Using neurotechniques imaging, Phillips, Klein, Mercier \& de Boysson (2006) explored within- and between-language processing of spoken single words in English-French bilinguals. The findings appeared to challenge the predictions of the Revised Hierarchical Model. The RHM holds that $\mathrm{L}_{2}-\mathrm{to}_{\mathrm{L}}-\mathrm{L}_{1}$ translations employ the strong links between the $\mathrm{L}_{2}$ and $\mathrm{L}_{1}$ lexical representations, whereas $\mathrm{L}_{1}-$ to- $\mathrm{L}_{2}$ translations are mediated via conceptual connections. In contrast, Phillips et al. (2006) found that conceptual processing was more strongly employed in $\mathrm{L}_{2}-$ to- $\mathrm{L}_{1}$ translations, i.e. lexical information of the $\mathrm{L}_{1}$ translation equivalent was not activated.

The role of attention during implicit memory retrieval can also be assessed using tests of priming. Theories assuming limited attentional capacity and cognitive resources in humans provide valuable insights into the cognitive processes of interest. For bilinguals, memory retrieval of $\mathrm{L}_{2}$ knowledge frequently occurs during interactions. They often have to juggle several tasks simultaneously. Although understanding the role of attention in second language acquisition have at the forefront of investigations, studies on dual-task demands at encoding and retrieval on bilingual memory is a more recent development in the literature (Declerck \&Kormos, 2012; Cook \& Meyer, 2008; Fernandes, Craik, Bialystok, \& Kreuger, 2007).

Studies that examine divided attention during retrieval have reported different results. Baddeley, Lewis, Eldridge and Thomson (1984) investigated the attention manipulation effects on both memory encoding and retrieval. They found that DA during retrieval produced little decline in memory accuracy. Based on their findings, they concluded that retrieval processes are wholly automatic. However, Craik, Govoni, Naveh-Benjamin, and Anderson (1996) did not agree on this conclusion. Their findings replicated the results in Baddeley et al. (1984) regarding the decline of memory accuracy in DA condition during memory retrieval but not because it is automatic. Craik et al. (1996) suggested that retrieval increases the reaction times on the accompanying secondary task to protect its own accuracy. According to their view, retrieval processes are obligatory and division of attention does not hinder them.

In a trend of bilingual studies, divided attention paradigm have been used to demonstrate the bilingual advantage for cognitive processing to control attention and inhibition (e.g Morales, Gómez-Ariza \& Teresa Bajo, 2013; Paap \& Greenberg, 2013; Prior, 2012). In a study of 104 monolingual and bilingual participants, Fernandes et al. (2007) manipulated attention to show interference effects from divided attention at encoding and retrieval on memory performance. A list of words from the same semantic category was presented auditorally and the participants free-recalled them aloud for a subsequent memory test. During both study and test phase, the word list was presented alone under FA conditions or concurrently with a visual identification task. Aging and bilingual status were considered as mediating factors. Distractory concurrent task words were either from the same category as the memory task words or were different from that in the memory task. Fernandes et al. (2007) found that the secondary task reduced performance more when it was performed at encoding rather than retrieval. They also reported that semantic association between the memory and secondary task significantly increased the memory interference.

The present study aims to reveal some vital facts concerning between-language spoken-word processing in Persian-English bilinguals using behavioral measures. The intention here is to examine how $\mathrm{L}_{2}$ learners' attention to semantic properties of spoken words influences the degree to which translation priming is involved 
in $\mathrm{L}_{2}$ spoken-word processing. We were interested in identifying whether unbalanced proficient bilinguals display symmetrical patterns of translation priming in auditory modality even if the attention is manipulated. The findings of the present study can also provide evidence about on-line availability of conceptual information when participants listen to words that change from the weaker to the stronger language and vice versa. The other goal is to explore the effect of divided attention during implicit retrieval in bilingual memory. It aims to examine effects of divided attention across different types of priming tasks as implicit tests on bilingual implicit memory efficiency or automaticity. In case DA has little effect on bilingual memory retrieval, this conclusion can be prompted that lexical retrieval is largely automatic or the secondary task has been scarified to save memory test.

\section{Method}

\subsection{Experiment 1: Translation Priming from $L_{2}$ to $L_{1}$}

Experiment 2 explored effects of translation priming in $\mathrm{L}_{2}$ to $\mathrm{L}_{1}$ direction regarding reaction time and accuracy in DA and FA conditions. It also aimed to examine secondary task costs and the detrimental effects of secondary task on the performance of priming magnitude.

\subsubsection{Participants}

Sixty participants (35 women, 25 men), native speakers of Persian $\left(\mathrm{L}_{1}\right)$ were recruited and compensated for their time. They were between 24 and 40 years of age. The mean age was 32 years $(S D=2.17)$. All were right handed and have normal hearing with no history of language disability or neurological insult.

It was important to determine the age of acquisition, level of proficiency in $\mathrm{L}_{1}$ and $\mathrm{L}_{2}$, type of learning system and amount of exposure to both language because language history of bilinguals could significantly affect the magnitude of the priming effects. All participants were asked to fill out the Persian version of the Language Experience and Proficiency Questionnaire (LEAP-Q, Marian, Blumenfeld, \& Kaushanskaya, 2007) to verify that they were all native speakers of Persian and had a comparable level of proficiency in English and to determine the self-reported level of $\mathrm{L}_{2}$ proficiency, $\mathrm{L}_{2}$ exposure and $\mathrm{L}_{2}$ experiences as well. The LEAP-Q is a reliable questionnaire that elicits internally consistent self-reported data about age of acquisition, $\mathrm{L}_{2}$ history, $\mathrm{L}_{2}$ proficiency and current exposure to $\mathrm{L}_{2}$. The Cronbach alpha reliability index turned out to be 0.79 . We analyzed their ratings to compute a mean proficiency score in Persian and one in English. Participants were considered as unbalanced bilinguals who rarely encountered English in their daily lives. All participants gave the highest percentage of time of exposure to their $\mathrm{L}_{1}$ identifying it as their marked or dominant language. Self-rating scale with 0 being no ability at all and 10 being perfect ability revealed that participants rated their $\mathrm{L}_{1}$ proficiency at or near 10 . They rated their $\mathrm{L}_{1}$ proficiency on all three measures significantly higher than the correspondingly $\mathrm{L}_{2}$ measures: $t(59)=-9.825, p<0.005$ for level of proficiency in speaking; $t(59)=-10.343, p<0.005$ for level of proficiency in understanding spoken language; $t(59)=-6.315, p<0.005$ for level of proficiency in reading. Table 1 shows language history and self-reported proficiency data for all participants.

Table 1. Background and language proficiency of the participants according to the Language Experience and Proficiency Questionnaire (LEAP-Q)

\begin{tabular}{|c|c|c|}
\hline Sex & $35 \mathrm{f}, 25 \mathrm{~m}$ & \\
\hline Years of formal education & $19.82(4.47)$ & \\
\hline Age of first exposure to $\mathrm{L}_{2}{ }^{\mathrm{a}}$ & $9.12(2.51)$ & \\
\hline Years of exposure to $L_{2}$ & $13.11(3.78)$ & \\
\hline Time spent in an English speaking country ${ }^{\mathrm{b}}$ & $2.45(1.83)$ & \\
\hline & $\mathrm{L}_{1}$ & $\mathrm{~L}_{2}$ \\
\hline Percentage of current exposure & $89.24(3.91)$ & $21(7.10)$ \\
\hline General level of proficiency $^{c}$ & $9.87(0.72)$ & $7.2(1.10)$ \\
\hline Level of proficiency in speaking ${ }^{c}$ & $9.76(0.82)$ & $7.98(1.20)$ \\
\hline Level of proficiency in understanding spoken language ${ }^{c}$ & $9.78(0.65)$ & $7.85(1.25)$ \\
\hline Level of proficiency in reading ${ }^{c}$ & $9.23(1.16)$ & $8.2(1.87)$ \\
\hline
\end{tabular}

${ }^{\mathrm{a}}$ In years; ${ }^{\mathrm{b}}$ In month; ${ }^{\mathrm{c}}$ Scale 1-10. Standard deviations are provided within parentheses

\subsubsection{Materials and Apparatus}

Both experiments were carried out in a computer controlled environment using the following software and hardware: Microsoft .NET Framework 3.5, SQL Server Express, specially developed software with C\#, Adobe 
Audition CS6, Acer Notebook 2750G with hard disc capacity of $500 \mathrm{~GB}$, a unidimensional head-mounted microphone (SM10A), a wireless optical mouse and a high fidelity stereo headphone.

The materials consisted of a list of 100 pairs with 30 translation word pairs including an English prime word followed by its translation in Persian and 70 unrelated word pairs including an English prime word followed by an unrelated Persian word. With no lexical database to obtain the Persian targets of word pairs, we had to conduct a pilot study. Three hundred high frequency Persian words were extracted from Persian Linguistic Database (http://pldb.ihcs.ac.ir; Assi, 1997). They were pretested with 200 Persian speakers at Islamic Azad University (120 women and 80 men, mean age 25, range 18-30) who participated for the course credit to ensure that the participants were familiar with the words included in the experiments. They rated their familiarity with each word on a 7-point scale $(1=$ unfamiliar word, $7=$ familiar word $)$. Two hundred and fifty Persian words whose mean familiarity score was 5 or higher were selected and then their concreteness was rated on a 7-point scale of concreteness. The meaning of a word that received a rating of 7 can be directly experienced by the senses (7=highly concrete). A rating of 1 showed that the meaning cannot be experienced directly by the senses (1=highly abstract). Words with a concreteness value of 5 or higher would be used for translation priming test. Words greater than 3 syllables in length and identical cognates were avoided to obtain 100 targets for the word pairs of this experiment (See Appendix A).

A group of 20 Persian-English bilinguals (from the same population as the participants in the experiments) was asked to give a spontaneous English translation for the Persian items $\left(\mathrm{L}_{1}-\mathrm{L}_{2}\right.$ translation). Those translations provided identically by $80 \%$ of the participants were considered as the primes in this experiment. The stimuli were stored with a 5-s interstimulus interval (ISI) between each two trials. There is a $150 \mathrm{~ms}$ stimulus onset asynchrony (SOA) length, i.e. the time interval between the offset of the prime and the onset of the target in each pair. The recordings took place in a sound-attenuated booth. The words were visually presented on a computer at a time with a 5-s interstimulus interval (ISI). The speaker $\left(\mathrm{L}_{1}=\right.$ Persian; high proficiency in English as her $\left.\mathrm{L}_{2}\right)$ was asked to read the words aloud as naturally as possible. Their production was recorded and edited using the software Adobe Audition CS6 and the unidimensional head-mounted microphone. The recorded words were digitized at $16 \mathrm{kHz}$, ramp off during the first and last $15 \mathrm{~ms}$ to eliminate audible clicks, and normalized for peak intensity and perceived loudness.

An artificial decision task was used as the secondary task. It consisted of 45 words (10 fillers) taken from the MRC Psycholinguistic Database (Coltheart, 1981; Wilson, 1998). The selected words were all nouns selected from a list of 200 words with a mean frequency of 296 occurrences per million (range $=70-1592$ ), a mean number of 2.2 syllables (range $=1-3$ ), a mean familiarity value of 471 (range $=300-700$ ) and a mean concreteness value of 541 (on a scale of 300-700).

\subsubsection{Procedure}

The experiments were run using software produced for this project. Participants were tested individually in a single session in this experiment. They were fitted with a pair of headphones and seated in front of a computer equipped with a mouse. The written instructions were given in English and oral additional explanations in Persian. The prime was presented to the right ear, and the target was presented to the left ear. The prime was to be ignored. Participants were told to perform a speeded semantic classification (living/nonliving) in which Persian target words were either primed by their English translations or unprimed (an unrelated English word). To identify the possible problems or confusions in the administration of the software and equipments, we conducted pilot study.

A half of the participants performed the task in isolation (the FA condition). The remaining participants performed the task with a secondary task (the DA condition) and one secondary task trial was presented simultaneously with the onset of the test word. In total, 100 auditory trails as memory test and 100 visual trials as secondary task were presented simultaneously. In the secondary task, the items were presented visually on a monitor and the participants were instructed to use the mouse to click on the correct box. The participants were told that the both tasks are equally important, and to perform both tasks as quickly and accurately as possible.

The artificial decision task was a semantic categorization test that involved meaning judgment. The participants were instructed to decide whether the word presented on the screen referred to something natural or man-made. For example, carpet is man-made or artificial, whereas rain is naturally occurring. Ambiguous items, e.g. oil, mouse, were avoided. Task instructions were displayed on the computer screen. Participants who participated in the DA condition tasks carried out the same secondary task as the pre-test baseline measure as well. It was later used to compare with its performance in the divided attention condition in both experiments. 


\subsubsection{Results}

Reaction time is the length of time between the offset of the stimulus and the onset of the response. RT results reflect mean reaction times for correct trials. RTs less than $500 \mathrm{~ms}$ coded as a non-response were excluded. The accuracy was calculated by dividing the number of correct responses by the total number of trials multiplied by 100 .

The mean RTs for primed and unprimed words in both the full and divided attention conditions are presented in Table 2. The proportion accuracy and mean reaction time (RT) to correct replies as two dependent variables were submitted to two separate $2 \times 2$ mixed factorial design with Priming Condition (Primed, Unprimed) manipulated within subjects and Attention Condition at retrieval (Divided Attention, Full Attention) manipulated between subjects. Data analysis was performed using SPSS 16.0. All alpha-levels were set at 0.05 for ANOVA.

Table 2. Experiment 2 mean RT for translation word pairs and unrelated word pairs in FA and DA condition

\begin{tabular}{lcccccc}
\hline & \multicolumn{3}{c}{ Translation word pairs } & \multicolumn{3}{c}{ Unrelated word pairs } \\
\cline { 2 - 7 } Attention condition & $\mathrm{N}$ & $\mathrm{M}$ & $\mathrm{SD}$ & $\mathrm{N}$ & $\mathrm{M}$ & $\mathrm{SD}$ \\
\hline FA & 30 & 1903 & 220.8 & 30 & 2324 & 411.2 \\
DA & 30 & 2772 & 572.2 & 30 & 2742 & 561.7 \\
\hline
\end{tabular}

Note: $\mathrm{FA}=$ Full Attention; $\mathrm{DA}=$ Divided Attention; $\mathrm{RT}=$ Reaction Time in millisecond

There was a main effect of priming, $F(1,58)=48.6, P=.000$, showing faster RTs for the translation words that unrelated word pairs and a significant interaction between priming condition and attention condition, $F(1,58)=$ 64.8, $P=.000$ (See Figure 1), indicating that magnitude of translation priming effects was larger in the FA condition. RTs differed significantly between the two conditions, $F(1,58)=30.53, P=.000$, being faster in the FA condition.

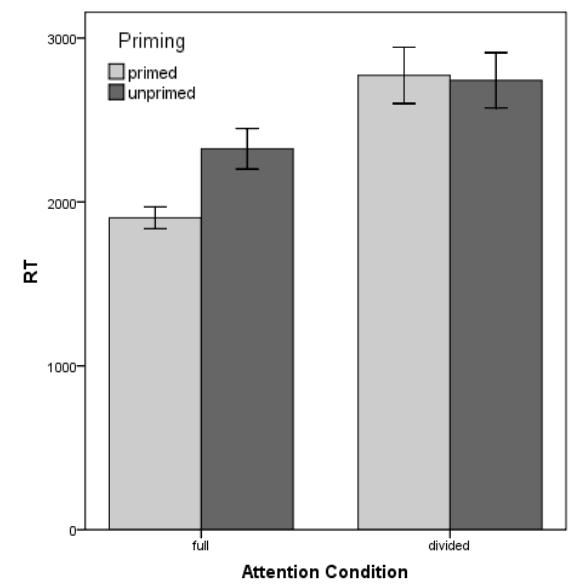

Figure 1. RT for memory test performance in Experiment 1 as a function of attention condition (full-divided) and priming status (primed-unprimed)

Accuracy data were analyzed in each attention condition using mixed 2 (Priming Condition) $\times 2$ (Attention Condition) ANOVA with the first factor being within- and the other factor between-subject manipulations, using accuracy as the dependent measure (See Table 3).

Table 3. Experiment 2 mean accuracy for primed and unprimed words in FA and DA condition

\begin{tabular}{lcccccc}
\hline & \multicolumn{3}{c}{ Translation word pairs } & \multicolumn{3}{c}{ Unrelated word pairs } \\
\cline { 2 - 7 } Attention condition & $\mathrm{N}$ & $\mathrm{M}$ & $\mathrm{SD}$ & $\mathrm{N}$ & $\mathrm{M}$ & $\mathrm{SD}$ \\
\hline FA & 30 & 60.17 & 15.627 & 30 & 47.10 & 13.674 \\
DA & 30 & 42.63 & 16.083 & 30 & 40 & 15.601 \\
\hline
\end{tabular}

Note: RT= Reaction Time; DA=Divided Attention; FA=Full Attention 
Repeated measure ANOVA yielded a significant effect of translation priming on accuracy, $F(1,58)=151.1, P$ $=.000$. A significant interaction between priming condition and attention condition, $F(1,58)=66.84, P=.000$ was found, indicating that responses to translation word pairs were more accurate in the FA condition and dividing attention could reduce translation priming effects in $\mathrm{L}_{2}-\mathrm{L}_{1}$ direction (See Figure 2). The correlation between attention condition and accuracy in Experiment 2 was found to be significant, $F(1,58)=10.01, P=.002$, showing that responses were more accurate in the FA condition .

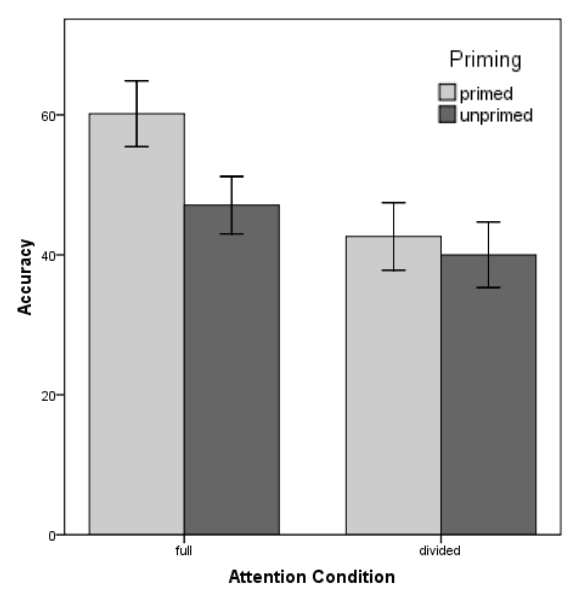

Figure 2. Accuracy for memory test performance in Experiment 1 as a function of attention condition (full-divided) and priming status (primed-unprimed)

Secondary task performance was measured on accuracy and RT using the same data analysis procedures as in Experiment 1 . The only difference is that the costs associated with priming are assessed by comparing secondary task performance during translation word pairs and unrelated pairs separately. There were secondary costs on RTs, $\mathrm{t}(59)=-4.76, \mathrm{p}<.0005$ and accuracy, $\mathrm{t}(59)=4.93, \mathrm{p}<.0005$. In general, significantly more errors and slower correct responses were revealed in DA condition.

\subsubsection{Discussion}

The data from Experiment 1 that aimed to study translation priming effects in $\mathrm{L}_{2}$-to- $\mathrm{L}_{1}$ direction indicate that significant priming effects were observed in the FA condition. Despite the high level of priming in the FA condition, the DA condition reduced priming. This was true for both RT and accuracy measures. Primed words were retrieved faster and more accurately in the FA condition. This was true for unprimed words as well. In other words, DA has significant effects on bilingual memory retrieval in this experiment. Besides the deficits produced by the secondary tasks to implicit memory, it was found that implicit retrieval in $\mathrm{L}_{2}$-to- $\mathrm{L}_{1}$ translation produced secondary costs in terms of RT and accuracy.

\subsection{Experiment 2: Translation Priming from $L_{1}$ to $L_{2}$}

Experiment 2 examined magnitude of translation priming in $L_{1}$ to $L_{2}$ direction in terms of behavioral measures in DA and FA conditions. The results were compared with those of Experiment 1 to find differences between within- and between-language priming effects and with those of Experiment 2 to explore the role of language direction in priming effects. The secondary task costs were also investigated.

\subsubsection{Participants}

Participants were identical to those tested in the first experiment.

\subsubsection{Materials and Apparatus}

The 100 English word targets satisfied the following criteria, i.e. a relatively high word frequency, a high degree of concreteness and a maximum length of no more than 500 milliseconds, taken from the MRC Psycholinguistic Database (http://psy.uwa.edu.au/mrcdatabase/uwa_mrc.htm; Coltheart, 1981; Wilson, 1998). The recorded words have a mean concreteness value of 558 (on a scale of 300-700) and a mean familiarity value of 540 (on a scale of 300-700). They spanned a range of written frequency (on a scale of 70-1592), with a mean of 347 (Kurčera \& Francis, 1967). They were on average 2.3 syllables long (range $=1-3$ ). Another constraint, particular 
to the auditory presentation of words, required that all words be unambiguous when presented auditorally, i. e., homophones such as tail - tale could not be used. Pilot testing assured that the words were understandable (see Appendix B).

In the stimuli, 30 translation word pairs include a Persian prime word followed by its translation in English and 70 unrelated word pairs including a Persian prime word followed by an unrelated English (participants' $\mathrm{L}_{2}$ ) word. A group of 20 Persian-English bilinguals (the same as those in Experiment 1) was asked to give a spontaneous Persian translation for the English targets $\left(\mathrm{L}_{2}-\mathrm{L}_{1}\right.$ translation). Those translations provided identically by $80 \%$ of the participants were considered as the primes in this priming experiment. The ISI $(5000 \mathrm{~ms})$ between each two trials, SOA length $(150 \mathrm{~ms})$ and the way we recorded the materials were identical to Experiment 1 . The materials of secondary task were selected from the list previously prepared.

\subsubsection{Procedure}

The design and procedure of the present experiment were identical to those of Experiment 1. Only the languages of primes and targets were reversed.

\subsubsection{Results}

Response times and the accuracy were calculated as the first experiment. The RT results for translation word pairs and unrelated word pairs presented in Table 4 were analyzed with a 2(Priming Condition) $\times 2$ (Priming Condition) mixed factorial ANOVA.

Table 4. Experiment 2 mean RT for translation word pairs and unrelated word pairs in FA and DA condition

\begin{tabular}{lllllll}
\hline \multirow{2}{*}{ Attention condition } & \multicolumn{4}{l}{ Translation word pairs } & \multicolumn{3}{l}{ Unrelated word pairs } \\
\cline { 2 - 7 } & $\mathrm{N}$ & $\mathrm{M}$ & $\mathrm{SD}$ & $\mathrm{N}$ & $\mathrm{M}$ & $\mathrm{SD}$ \\
\hline FA & 30 & 1848 & 224.562 & 30 & 2195 & 346 \\
DA & 30 & 2302 & 535.343 & 30 & 2662 & 519.591 \\
\hline
\end{tabular}

Note: FA= Full Attention; DA=Divided Attention; RT=Reaction Time in millisecond

The main effect of priming was significant, $F(1,58)=199.1, P=.000$, with translation word pairs being retrieved faster than unrelated words. Interaction of priming with attention was not significant, $F(1,58)=.064, P$ $=.8$, indicating that magnitude of translation priming effects was equivalent across each condition (See Figure 3 ). The main effect of attention condition as the between-subjects factor was significant, $F(1,58)=18.47, P=.000$, indicating that dividing attention resulted in slower RTs.

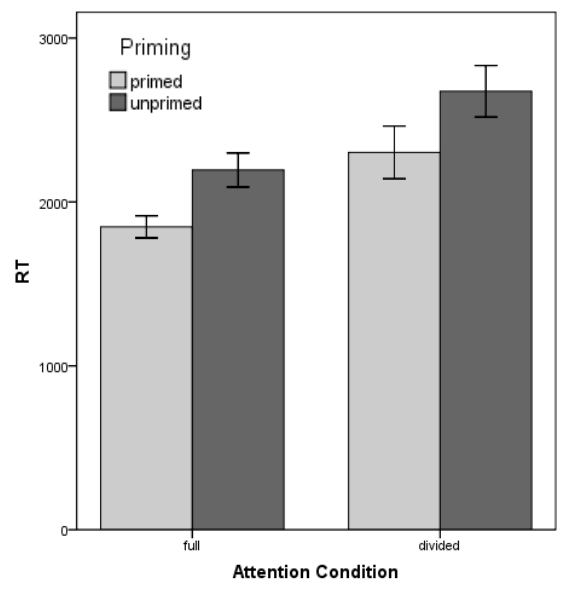

Figure 3. RT for memory test performance in Experiment 2 as a function of attention condition (full-divided) and priming status (primed-unprimed)

Accuracy results (See Table 5) were also submitted to a mixed 2 (Priming Condition) $\times 2$ (Attention Condition) ANOVA with the first factor as between- and the second factor as within-subject manipulations. 
Table 5. Experiment 2 mean accuracy for primed and unprimed words in FA and DA condition

\begin{tabular}{lllllll}
\hline \multirow{2}{*}{ Attention condition } & \multicolumn{4}{l}{ Translation word pairs } & \multicolumn{3}{l}{ Unrelated word pairs } \\
\cline { 2 - 7 } & $\mathrm{N}$ & $\mathrm{M}$ & $\mathrm{SD}$ & $\mathrm{N}$ & $\mathrm{M}$ & $\mathrm{SD}$ \\
\hline FA & 30 & 67.47 & 11.449 & 30 & 55.40 & 10.743 \\
DA & 30 & 49.60 & 12.013 & 30 & 39.93 & 10.445 \\
\hline
\end{tabular}

Note: $\mathrm{RT}=$ Reaction Time; DA=Divided Attention; FA=Full Attention

Repeated measure ANOVA yielded a main effect of translation priming on accuracy, $F(1,58)=323.94, P=.000$. There was no significant interaction between priming condition and attention condition, $F(1,58)=3.95, P=.057$ (See Figure 4). The correlation between attention condition and accuracy in Experiment 2 was significant, $F(1,58)=34.86, P=.000$, showing that dividing attention can lead to more errors.

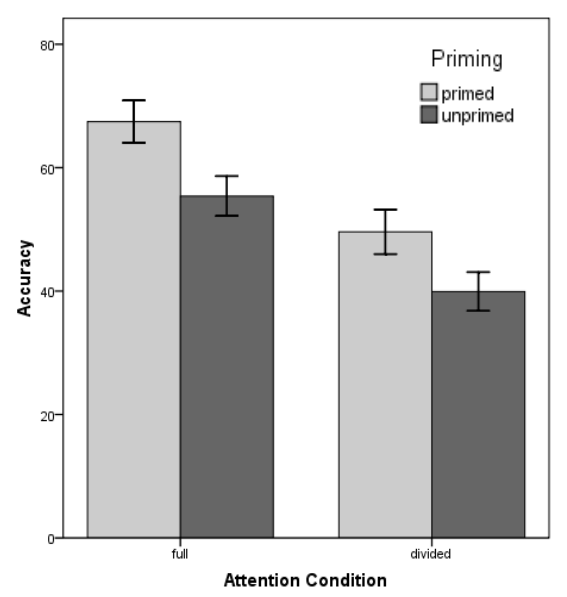

Figure 6. Accuracy for memory test performance in Experiment 2 as a function of attention condition (full-divided) and priming status (primed-unprimed)

Secondary task performance was measured on accuracy and RT using the same data analysis procedures as in Experiments 1 and 2. The only difference is that the costs associated with priming were assessed by comparing secondary task performance during translation word pairs and unrelated pairs separately. There were secondary costs on RTs, $t(59)=-5.9, p<.0005$. However, there was no main cots on accuracy of secondary tasks, $t(59)=$ $1.55, p=.125$.

\subsubsection{Discussion}

Experiment 2 that was designed to study translation priming effects in $\mathrm{L}_{1}$-to- $\mathrm{L}_{2}$ direction showed a significant priming effect from $\mathrm{L}_{1}$ to $\mathrm{L}_{2}$ under both FA and DA conditions. Although the magnitude of priming is not significantly different in two attention conditions, manipulation of attention had significant effects on memory retrieval for both RT and accuracy. Memory test in Experiment 2 produced robust secondary task costs for RT.

\section{General Discussion}

\subsection{Effects of Priming}

The results revealed that translation priming effects were present in both experiments when proficient bilinguals process words in the FA condition. In line with what RHM, BIA+ and BIA-d predict, some studies have obtained symmetric effects across both translation directions (Basnight-Brown \& Altarriba, 2007; De Groot \& Poot, 1997; Dunabeitia, Perea, \& Carreiras, 2010; Perea, Dunabeitia, \& Carreiras, 2008). This study produced results that cooperate the findings of these studies finding no interaction between translation priming and language direction in the FA condition. Significant translation priming was observed in both language directions in the FA condition.

With regard to the RHM, the link between the conceptual store and the $\mathrm{L}_{1}$ lexicon is stronger than the link between the conceptual store and the $\mathrm{L}_{2}$ lexicon. Therefore, magnitude of priming in the $\mathrm{L}_{1}-\mathrm{L}_{2}$ direction is higher than that obtained in the $\mathrm{L}_{2}-\mathrm{L}_{1}$ direction. For highly proficient native-like bilinguals, the RHM would predict a 
symmetric pattern of translation priming effects. However, for unbalanced bilinguals the RHM predicts that translation from $\mathrm{L}_{2}$ to $\mathrm{L}_{1}$ should be faster than from $\mathrm{L}_{1}$ to $\mathrm{L}_{2}$, due to the strong direct link of $\mathrm{L}_{2}$ words to their $\mathrm{L} 1$ translations. We did not find this asymmetrical translation priming across languages. The language history data collected on our participants revealed that the bilinguals were highly proficient still dominant in their $\mathrm{L}_{1}$ (Persian) at the time of the present study. The overall pattern of translation priming effects reported here cannot be accounted for by RHM framework. The pattern of translation priming effects is in line with the predictions of the developmental version of the BIA model (BIA-d). According to this model, as $\mathrm{L}_{2}$ proficiency approaches $\mathrm{L}_{1}$ proficiency, more symmetric pattern of performance can be seen, i.e. proficient bilinguals do not depend on the direction of translation because $\mathrm{L}_{2}$ word forms and conceptual representation are directly connected.

Hence, this pattern of result produced by this group of unbalanced bilinguals suggests that their high $\mathrm{L}_{2}$ proficiency makes them able to use similar amount of conceptual information to access words in both languages and priming is mediated conceptually. The presence of priming effect in the $\mathrm{L}_{2}$-to- $\mathrm{L}_{1}$ translation can be interpreted as evidence for the activation of both lexical and semantic information of the $\mathrm{L}_{1}$ translation equivalents. It can be argued that symmetrical patterns of translation priming result in more automatic access to lexicon and stronger L2 word from-to-meaning mappings.

\subsection{Effects of Divided Attention}

Attention condition could reduce priming magnitude in $\mathrm{L}_{2}$-to- $\mathrm{L}_{1}$ translation priming. Given the fact that in many studies in $\mathrm{L}_{1}$ (e.g. Baddeley et al., 1984; Craik et al., 1996; 1998; Naveh-Benjamin \& Guez, 2000; Naveh-Benjamin, Craik, Perretta, \& Tonev), automatic implicit retrieval is immune to divided attention, we expected similar automatic processing in highly proficient bilinguals. With regard to previous research (Bialystok, 2001; Bialystok, Craik, Klein, \& Viswanathan, 2004; Fernandes, Craik, Bialystok \& Kreuger, 2007) demonstrating enhanced attentional control in conflictive conditions, we assumed that highly proficient participants resist the effect of a simultaneous task that involves dividing attention and bilingual implicit memory is the result of automatic retrieval processes. However, the findings suggest that translation priming in $\mathrm{L}_{2}-\mathrm{L}_{1}$ direction do not reflect automatic retrieval processes.

With unbalanced proficient bilinguals, effects of similar magnitude appeared in the two language directions (namely, a symmetric pattern). However, surprisingly, the findings of translation priming in the DA condition do not accord our observations in the FA condition, i.e. priming effects are different when the language direction is $\mathrm{L}_{1}-\mathrm{L}_{2}$ from when it is $\mathrm{L}_{2}-\mathrm{L}_{1}$ in unbalanced bilinguals (namely, a symmetric pattern). For the $\mathrm{L}_{1}-$ to- $\mathrm{L}_{2}$ translation, manipulation of attention could not reduce priming while priming magnitude was not present for the $\mathrm{L}_{2}$-to- $\mathrm{L}_{1}$ translation in the DA conditions. It can therefore be assumed that divided attention can diminish the strength of the links between $\mathrm{L}_{2}$ lexicon and the concepts. In fact, the connections between $\mathrm{L}_{2}$ word forms and semantic representations are not strong enough to resist interference from a concurrent task.

Memory performance was significantly impaired across attention conditions in both experiments. We can explain this result considering the central bottleneck effect created in the functioning of the central execution under divided attention condition. Certain processes including memory retrieval require the use of a central bottleneck process and only one process have access to the bottleneck at anytime. Bottleneck models of memory (Pashler, 1994) assume that simultaneous performance of two tasks or operations results in one or both tasks being stalled, delayed, or impaired if they require a single mechanism for their operation. Therefore, the selection of a response to a secondary task should disrupt memory retrieval. The present findings seem to be consistent with other research (Gaspelin, Ruthruff, \& Pashler, 2013) which found that $\mathrm{L}_{2}$ retrieval is sensitive to bottleneck effects and is constrained by the processing limits of the central executive and bottleneck effect could impair it.

The other aim of the study was to demonstrate if retrieval produces large costs to secondary task type. In other words, the effects of memory retrieval on the secondary task were examined to study attentional demands of memory test. In Experiments 1, secondary task performance was disrupted by implicit tasks as reflected by both reduced accuracy and increased RTs. However, no main cost on accuracy was found in Experiment 2. There are different explanations for the results. First , costs may reflect the attentional cost of retrieval processes of implicit memory. This finding backs up the obligatory nature of implicit retrieval. Second, as the secondary tasks are presented in a different modality, the participants may show a preference to respond to auditory stimuli before visual one. Proficient bilinguals show the most automatic access to $\mathrm{L}_{2}$ lexicon in $\mathrm{L}_{1}-\mathrm{L}_{2}$ translation priming.

\section{Conclusion}

The current study provided a behavioral investigation of different priming effects and implicit retrieval in bilinguals with specific regards to spoken word processing speed and accuracy. The evidence has provided 
important information on issues far beyond these initial topics, not just into priming effects but into matters such as attention manipulations and bilingual memory performance in dual-tasking conditions in auditory modality. The conclusion that attention manipulation and implicit retrieval interact in $\mathrm{L}_{2}$ word processing is inevitable. However, the knowledge gained here regarding each of these factors may help to better understand the effects of attention on automaticity.

Taken together, this study used translation priming tasks and divided attention during the retrieval phase. The present experiments showed that translation priming can be generalized to auditory modality and unbalanced proficient bilinguals. The results provide evidence for symmetrical cross-language interactions in bilingual auditory word recognition. However, our study showed that the performance of bilingual memory depends on an overall ability to monitor attention. $\mathrm{L}_{2}$ learners can learn from auditory processing of $\mathrm{L}_{2}$ words but this is controlled by a few factors including the conditions of retrieval of the spoken input to which they are exposed. The results confirmed that high bilingual proficiency can enhance bilingual memory performance in different priming tasks. However, unbalanced bilinguals participated in our study did not demonstrate the level of second language fluency that was needed to exploit the divided attention skill.

Although we argue that the evidence we have presented is strongly suggestive of spoken word processing and retrieval processes in implicit memory in bilinguals, fuller exploration of the issue has to be left to future studies. An interesting question for future research with respect to the bilingual memory encoding and retrieval is whether attention manipulations have different consequences at retrieval and encoding processes. Future research should seek to demonstrate the cognitive differences between monolingual and bilingual children. The design of this study can be adapted to further compare the executive functions such as mental flexibility, attentional control, inhibitory control, and task switching in monolinguals and bilinguals in order to examine bilingual cognitive advantage.

\section{References}

Alvarez, R. P., Holcomb, P. J., \& Grainger, J. (2003). Accessing word meaning in two languages: an event-related brain potential study of beginning bilinguals. Brain and Language, 87, 290-304. http://dx.doi.org/10.1016/S0093-934X(03)00108-1.f2004.

Assi, M. (1997). Farsi Linguistic Database (FLDB). International journal of lexicography. V10. Euralex Newsletter.

Baddeley, A., Lewis, V., Eldridge, M., \& Thomson, N. (1984). Attention and retrieval from long-term memory. Journal of Experimental Psychology: General, 113, 518-540.

Basnight-Brown, D. M., \& Altarriba, J. (2007). Differences in semantic and translation priming across languages: The role of language direction and language dominance. Memory \& Cognition, 35, 953-965.

Bialystok, E. (2001). Bilingualism in development: Language, literacy and cognition. New York: Cambridge University Press.

Bialystok, E., Craik, F. I. M., Klein, R., \& Viswanathan, M. (2004). Bilingualism, aging, and cognitive control: Evidence from the Simon Task. Psychology and Aging, 19, 290-303.

Coltheart, M. (1981). The MRC Psycholinguistic Database. Quarterly Journal of Experimental Psychology, 33A, 497-505.

Cook, A. E., \& Meyer, A. S. (2008). Capacity demands of phoneme selection in word production: New evidence from dual-task experiments. Journal of Experimental Psychology: Learning, Memory, and Cognition, 34, 886-899.

Craik, F. I. M., Govoni, R., Naveh-Benjamin, M., \& Anderson, N. D. (1996). The effects of divided attention on encoding and retrieval processes in human memory. Journal of Experimental Psychology: General, 125, 159-180.

Declerck, M., \& Kormos, J. (2012). The effect of dual task demands and proficiency on second language speech production. Bilingualism: Language \& Cognition, 15(4), 782-796. http://dx.doi.org/10.1017/S13667289 11000629

De Groot, A. M. B., Dannenburg, L., \& Van Hell, J. G. (1994). Forward and backward word translation by bilinguals. Journal of Memory and Language, 33, 600-629.

De Groot, A. M. B., \& Poot, R. (1997). Word translation at three levels of proficiency in a second language: The ubiquitous involvement of conceptual memory. Language Learning, 47(2), 215-264. 
DeVitto, Z., \& Burgess, C. (2004), Theoretical and methodological implications of language experience and vocabulary skill: Priming of strongly and weakly associated words. Brain and Cognition, 55, 295-9.

Duñabeitia, J. A., Perea, M., \& Carreiras, M. (2010). Masked translation priming effects with highly proficient simultaneous bilinguals. Experimental Psychology, 57, 98-107.

Duyck, W. (2005). Translation and associative priming with crosslingual pseudohomophones: Evidence for nonselective phonological activation in bilinguals. Journal of Experimental Psychology: Learning, Memory, \& Cognition, 31, 1340-1359.

Fernandes, M. A., Craik, F. I. M., Bialystok, E., \& Kreuger, S. (2007). Effects of bilingualism, aging, and semantic relatedness on memory under divided attention. Canadian Journal of Experimental Psychology, 61, 128-141. http://dx.doi.org/10.1037/cjep2007014

Gaspelin, N., Ruthruff, E., \& Pashler, H. (2013). Divided attention: An undesirable difficulty in memory retention. Memory \& Cognition, 41, 978-988 http://dx.doi.org/10.3758/s13421-013-0326-5

Geyer, A., Holcomb, P. J., Midgley, K. J., \& Grainger, J. (2010). Processing words in two languages: An event-related brain potential study of proficient bilinguals. Journal of Neurolinguistics, 24, 338-351. http://dx.doi.org/10.1016/ j.jneuroling.2010.10.005

Grainger, J., Midgley, K., \& Holcomb, P. J. (2010). Re-thinking the bilingual interactive-activation model from a developmental perspective (BIA-d). In M. Kail, \& M. Hickmann (Eds.), Language acquisition across linguistic and cognitive systems (pp. 267-283). New York: John Benjamins.

Kroll, J. F., \& Stewart, E. (1994). Category interference in translation and picture naming: evidence for asymmetric connections between bilingual memory representations. Journal of Memory \& Language, 33, 149-174.

Kucera, H., \& Francis, W. N. (1967). Computational Analysis of Present-Day American English. Providence: Brown University Press.

La Heij, W., Hooglander, A., Kerling, R., \& Van der Velden, E. (1996). Nonverbal context effects in forward and backward word translation: Evidence for concept mediation. Journal of Memory and Language, 35, 648-665.

Marian, V., Blumenfeld, H., \& Kaushanskaya, M. (2007). The language experience and proficiency questionnaire (LEAP-Q): Assessing language profiles in bilinguals and multilinguals. Journal of Speech, Language, and Hearing Research, 50(4), 940-967.

Marian, V., \& Spivey, M. (2003). Bilingual and monolingual processing of competing lexical items. Applied Psycholinguistics, 24, 173-193.

Midgley, K. J., Holcomb, P. J., \& Grainger, J. (2009). Masked repetition and translation priming in second language learners: A window on the time-course of form and meaning activation using ERPs. Psychophysiology, 46, 551-565.

Morales J., Carlos J. Gómez-Ariza, \& Teresa Bajo, M. (2013). Dual mechanisms of cognitive control in bilinguals and monolinguals. Journal of Cognitive Psychology, 25(5), 531-546. http://dx.doi.org/10.1080/ 20445911.2013.807812

Naveh-Benjamin, M., Craik, F. I. M., Perretta, J. G., \& Tonev, S. T. (2000). The effects of divided attention on encoding and retrieval processes: The resiliency of retrieval processes. Quarterly Journal of Experimental Psychology, 53A, 609-625.

Naveh-Benjamin, M., \& Guez, J. (2000). Effects of divided attention on encoding and retrieval processes: Assessment of attentional costs and a componential analysis. Journal of Experimental Psychology: Learning, Memory, \& Cognition, 26, 1461-1482.

Paap, K. R., \& Greenberg, Z. I. (2013). There is no coherent evidence for a bilingual advantage in executive processing. Cognitive Psychology, 66, 232-258.

Phillips, N. A., Klein, D., Mercier, J., \& de Boysson, C. (2006). ERP measures of auditory word repetition and translation priming in bilinguals. Brain Research, 1125, 116-131. http://dx.doi.org/10.1016/j.brainres. 2006.10.002.

Pashler, H. (1994). Dual-task interference in simple tasks: Data and theory. Psychological Bulletin, 116, 220-244.

Prior, A. (2012). Too much of a good thing: Stronger bilingual inhibition leads to larger lag-2 task repetition 
costs. Cognition, 125, 1-12.

Schoonbaert, S., Hartsuiker, R. J., \& Pickering, M. J. (2007). The representation of lexical and syntactic information in bilinguals: Evidence from syntactic priming. Journal of Memory \& Language, 56, 153-171.

Wilson, M. D. (1988). The MRC Psycholinguistic Database: Machine readable dictionary, Version 2. Behavioural Research Methods, Instruments and Computers, 20(1), 6-11.

\section{Appendix A}

Auditory stimuli used in Experiment 1

\begin{tabular}{|c|c|c|}
\hline \multicolumn{2}{|c|}{ Unrelated word pairs (English-Persian) } & \multirow{2}{*}{$\begin{array}{l}\text { Translation word pairs (English-Persian) } \\
\text { Wife- همر }\end{array}$} \\
\hline Step- محقق & زن & \\
\hline Pig- شهز & Fund- آب & 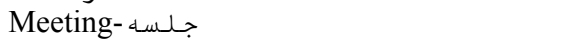 \\
\hline Scholar- رهبر & ترانه ت ت Ice- ت & Neighbor- هسائسه \\
\hline Room- شغل & خيابان -Gym & " رييس-Boss \\
\hline Tax- خواب & كاركر - Corn- & خانه Home- خانه \\
\hline Forest- شاعر & Rope- ماهى & Fruit- ميوه \\
\hline Cat- جاى & مربه - Damage & Bread- نان \\
\hline Life- دولت & زبان - Reason- & Child- بجه \\
\hline Earth- عماز & سع Fire- سع & Student- دانشجو \\
\hline Event- مشاور & ساعت Effect- & News- اخبار \\
\hline خوانتده Robber- & ليول - Demon & وزير -Minster- \\
\hline Wine- مسافرت & 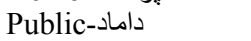 & Teacher- مe \\
\hline خاله - Target- & Price- تاريخ & Shop- فروشكاه \\
\hline Voice- بزشك & Sرد - Speech & خواهر - Sister- \\
\hline " بيمه - Mat- & Journey- ناهار & Shoe- كفش \\
\hline Terror- برنده & Defense- ميز & Unو Uncle- \\
\hline Name- سال & كوسفند - Discussion & فرش Carpet- ف \\
\hline عروسى Theory- & Income- دايى & Fذا Food- \\
\hline رانتده -Window & Egg- عمل & Author- نويسنده \\
\hline Parent- دوست & Peach- روزنامه & University- دانشعاه \\
\hline بسر River- & كاسب Game- كاسب & Presenter- مجرى \\
\hline Clay- ماهواره & Stuff- انسان & School- مدرسه \\
\hline Court- بازار & شب Crew- شب & شوهر-Husband \\
\hline Silence- كياه & كوجهه -Form & Thief- دزد \\
\hline EكS East- سكة & مرغ & Nفتر - Notebook \\
\hline Tرخت Temple & Director- يرستار & Chef- آششيز \\
\hline Hall- ازدواج & عistory- عكس & bride- عروس \\
\hline آرايش - Attack- & Fiction- مهندس & لباس Clothes- لب \\
\hline Island- ورزش & صبح - Candle- & وكيل -Lawyer- \\
\hline Suburb- مردم & نمكى Person & \\
\hline Blood- مهمانىى & Question- بازيكر & \\
\hline Color- تعطيلى & كاغذ - Voice & \\
\hline Pen- فرش & Bill- استاد & \\
\hline Custom- تاجز & ملى - مل & \\
\hline Plane- مورجه & ينجره-Work & \\
\hline
\end{tabular}

\section{Appendix B}

Auditory stimuli used in Experiment 2

\begin{tabular}{|c|c|c|}
\hline \multicolumn{2}{|c|}{ Unrelated word pairs (Persian- English) } & Translation word pairs (Persian- English) \\
\hline 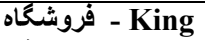 & - Course & إضى - Judge \\
\hline ق - Law & - روح - Sound & Answer - A Aاسخ \\
\hline Food - فاصله & - Children & People - مردم - Pe \\
\hline Boy - قاشثق & Barber & - Child - بجه \\
\hline - Teacher & Congress - سركرمى - Co & شهر - Town \\
\hline Thing - Tروس - Thing & 1 بلكان - Degree & School S - Sدرسه \\
\hline Firm - Fاغذ - Firm & 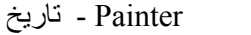 & Doctor \\
\hline - Table- & - Pig - شانه & - Year \\
\hline - Friend & | - Heart - جزيره & - Horse \\
\hline Subject - فردا - Sub & Interest - حمله & Country - Cشور - C \\
\hline ～ا متن - Result & ق قفسه & - Teeth - دندانها \\
\hline N & - Baby & - طراح - Designer \\
\hline - Human & - Council - شب - & Hospital \\
\hline
\end{tabular}




\begin{tabular}{|c|c|c|}
\hline \multicolumn{2}{|c|}{ Unrelated word pairs (Persian- English) } & \multirow{2}{*}{$\begin{array}{l}\text { Translation word pairs (Persian- English) } \\
\text { - Pilot }\end{array}$} \\
\hline - Road - فشار - Road & - Employer & \\
\hline - Water - نسل & - River - خانهدار & L شواهد - Evidence \\
\hline - Direction - زندكى & تماشـ - Season & - Church \\
\hline - Writer - صندلى & - شهرت - Lion & Audience \\
\hline - Girl - فكر & - Priest - آجر - & Husband - شوهر - H \\
\hline Lunch & Reason & سر - Head \\
\hline Cousin - مذهب & Fire - حساب & President - رئيس جمهور \\
\hline - Question - بازاز - - & - Councilor & Equipment - تجهيزات \\
\hline ميز - Parent & Night - تماس - N & Governor - فرماندار \\
\hline Officer - مزرعه & - Bird & Problem - مشكل \\
\hline Picture - واقعيت & - Temperature & Nature - مبيعت \\
\hline Poet - ليوان - Pot & - Spring انتشار ات - S & Secretary - منشى - Sect \\
\hline Host - غروب - غرو & - Student & Staff \\
\hline Person - ت شكار - Pen & هفته - Artist & |جر| - Performance \\
\hline - Book & Plant - مسافر - Plan & Property - ملى Pro \\
\hline Hour - مجلْس & Statement - قيجִى & - Chief - رئيس \\
\hline & جک - M - Money & - thief \\
\hline Dentist & - Actress - امكانات & \\
\hline Dog - شيوه & - Rabbit - مداد & \\
\hline Summer - فرار & South - حساب & \\
\hline Adult - ميوه & زمين - face & \\
\hline - Week - قايق & lawyer - سيب & \\
\hline
\end{tabular}

\section{Copyrights}

Copyright for this article is retained by the author(s), with first publication rights granted to the journal.

This is an open-access article distributed under the terms and conditions of the Creative Commons Attribution license (http://creativecommons.org/licenses/by/3.0/). 